\title{
Improving Fourth Grade Students' Critical Thinking Skills with MIKIR Approach
}

\author{
Mahmud Alpusari ${ }^{1 *}$, Eva Astuti Mulyani ${ }^{1}$, Neni Hermita ${ }^{1}$, Elpri Darta Putra ${ }^{2}$ \\ ${ }^{1}$ Department of Elementary Teacher Education, Faculty of Teacher Training and Education, University of \\ Riau, Pekanbaru, Indonesia \\ ${ }^{2}$ Department of Elementary Teacher Education, Faculty of Teacher Training and Education, Islamic \\ University of Riau, Pekanbaru, Indonesia \\ *mahmud.Aalpusari@lecturer.unri.ac.id
}

Received: July $25^{\text {th }}, 2020$

Revised: August $18^{\text {th }}, 2020$

Accepted: August $20^{\text {th }}, 2020$

Abstract

This study aims to evaluate the implementation of an approach to improve elementary school students' critical thinking skills. The approach is called MIKIR that stands for mengalami (experiencing), interaksi (interaction), komunikasi (Communication), internalisasi (internalization), and refleksi (reflection). This research was conducted at a public elementary school in Pasir Penyu District, Indragiri Hulu Regency, Indonesia. The subject of this research was 23 fourth grade students. The method used in this research was quasi-experimental method. The experimental design used in this study was pre-test and post-test one group design. The results of the study obtained an average pretest score of 22.13 and an average posttest score of 27.70 from a maximum score of 36 . Based on these results, the score increased by 5.57 points or $20.10 \%$. The overall average $\mathrm{N}$-gain value of 0.41 with moderate criteria, so that the MIKIR approach can improve fourth grade students' critical thinking skills. This result was supported by the results of student learning activities and student responses to learning with the MIKIR approach obtaining an average of $84.6 \%$ with a very good category.

Keywords: critical thinking skills; learning activities; MIKIR learning approach.

\section{INTRODUCTION}

Learning is a major aspect in education. If you want to improve the quality of education, you need to start from the learning done by teachers and students at school. This means that teachers must make every effort to condition learning to become a meaningful process in shaping students experiences and abilities. The teacher's efforts will determine the process, direction and learning outcomes. The learning process also not only accepts information, ideas and skills, but the learning process also includes the reconstruction of new ideas or knowledge by the mind. Humans must construct this knowledge and give meaning through real experiences (Thobroni \& Mustofa, 2013, p.107-108). 
So, the core of the learning process is the process of knowledge construction.

Learning approach has an important role in the teaching and learning process. In addition, the learning approach can also delivery the message to be delivered in each subject. According to Sanjaya (2008, p.127) "The approach can be said to be a starting point or our point of view towards the learning process. The term approach refers to the view on the occurrence of a process which is still very general in nature. The application of learning approaches in schools, teachers can create a learning atmosphere that attracts attention by utilizing learning creative, innovative and varied learning approaches so that learning can take place by optimizing students' abilities. Lots of learning approaches are used in the teaching and learning process. In order to obtain satisfactory things an approach is needed to teach a knowledge or material so that it is as expected.

The approach is interpreted as a point of view of the learning process (Rusman, 2012). Meanwhile, according to Komalasari (2013) the learning approach is interpreted as a point of view of the learning process, which refers to the view of the occurrence of a process that is still very common in which eccomodate, inspires, strengthens, and underlies learning methods with a certain theoretical scope. The approach is the initial step of forming an idea in looking at a problem (Sanjaya, 2008). So, the approach is the point of view of the learning process that is still general then strengthened using appropriate learning models and methods.

In this research the authors application a MIKIR approach, the MIKIR consists of five stages namely mengalami (experiencing), interaksi (interaction), komunikasi (communication), internalisasi (internalization) and refleksi (reflection) (Alpusari et all, 2019). With the MIKIR approach, students experience the learning process by interaction and communication in learning. In addition, students are able to internalition character values in every day. The elements of the MIKIR approach can be seen in table 1.

The process for obtaining information/data uses the senses (eyes, ears, nose, skin, tongue). Usman Samatowa (Patta Bundu, 2006), argues that observing is a basic skill that must be had by everyone in conducting scientific investigations (the basic of all scientific inquiry is observation), and must be had by students.

Some of the behaviors that students working during observation include: (1) the use of the senses not only vision, (2) organizing objects according to one particular trait, (3) identifying many the nature, (4) making quantitative observations, and (5) make qualitative observations. (Trianto, 2010).

Interaction is a type of action that occurs when two or more objects affect or have an effect on one another. Actions are seen in an activity in the learning process where interaction is a communication in small groups in 
delivering mind, ideas between two or more people.

Table 1. Elements of the MIKIR Approach

\begin{tabular}{|c|c|c|}
\hline No & MIKIR Approach & Description \\
\hline 1 & MENGALAMI (Experiencing) & $\begin{array}{l}\text { Make observations / experiments / interviews during the } \\
\text { learning process. }\end{array}$ \\
\hline 2 & INTERAKSI (Interaction) & $\begin{array}{l}\text { The process of exchanging mind / ideas between two or } \\
\text { more people, and responding to the ideas / opinions of } \\
\text { others. }\end{array}$ \\
\hline 3 & $\begin{array}{l}\text { KOMUNIKASI } \\
\text { (Communication) }\end{array}$ & $\begin{array}{l}\text { The process delivery ideas / thoughts or feelings by } \\
\text { someone to others, through oral and written, delivering the } \\
\text { work, reporting the results of experiments, and reporting } \\
\text { the results of group discussions. }\end{array}$ \\
\hline 4 & $\begin{array}{l}\text { INTERNALISASI } \\
\text { (Internalisation) }\end{array}$ & $\begin{array}{l}\text { Planting of one's behavior, attitudes, and values that it gets } \\
\text { in the learning process. }\end{array}$ \\
\hline 5 & REFLEKSI (Reflection) & $\begin{array}{l}\text { Activities look back on learning experiences and take } \\
\text { lessons to learn better in the future. }\end{array}$ \\
\hline
\end{tabular}

Hornbaek, K \& Oulasvirta (2017) argument an interaction, grossly speaking, is a transaction between two entities, typically an exchange of information, but it can also be an exchange of goods or services. Velentzas, J and Broni, G (2014) The term "communication" has been derived from the Latin "communis," that means "common". Thus "to communicate" means "to make common" or "to make known", "to share" and includes verbal, nonverbal and electronic means of human interaction. Scholars who study communication analyze the development of communication skills in humans and theorize about how communication can be made more effective.It is the mean.

Communication can be defined as the process of transmitting information and common understanding from one person to another (Keyton, 2011: Lunenburg, 2010). The word communication is derived from the Latin word, communis, which means common. The definition underscores the fact that unless a common understanding results from the exchange of information, there is no communication. Figure 1 reflects the definition and identifies the important elements of the communication process (Cheney, 2011; Lunenburg, 2010).

Etymologically, internalization shows a process. In the Indonesian language can be defined as a process. In the large Indonesian dictionary internalization is defined as appreciation, deepening, mastery in depth that goes on through fostering, guidance and so on (Alwi, 2007).

In relation to internalization, Muhadjir in Sunarti et al (2014) argues that internalization is an interaction that give influences the acceptance or rejection of values, more influences on 
personality, evaluative functions become more dominant.

The process of thinking about the meaning of learning experienced, both related to the material being studied and the learning experience. Reflection is an activity to restate what has been done. Reflection is also often referred to as "bouncing." In this case, the researcher seems to reflect his experience in the mirror, so that his vision is clear, both weaknesses and weaknesses.

Based on the above it is necessary to have a study entitled Developing the development of the MIKIR approach to improve the critical thinking skills of elementary school students. The purpose of this paper is the extent to which the MIKIR approach can improve the critical thinking skills of elementary school students.

\section{METHODS}

This type of research is quantitative research. The method used in this research is quasi-experimental method. The experimental design used in this study is Pre-Test and Post-Test one Group Design. At the beginning of the learning activity, students are given a test (pretest) to determine students' initial ability to critical thinking skills before being given treatment. Then students are given treatment in the form of implementing MIKIR learning on Theme 1 , sub-theme 1 to sub-theme 2 . The application of the MIKIR approach is given for 15 meetings. After being given treatment, at the end of the learning process students are given a test (posttest) to determine the students 'final ability towards students' critical thinking skills. Thus the results of treatment can be known to be more accurate because it can compare with the situation before being treated (Sugiyono, 2014, p.74). This design is used in accordance with the objectives to be achieved, namely to determine the increase in critical thinking skills by applying the MIKIR learning approach to elementary school students.

This research was conducted in grade IV SDN 007 Sekar Mawar, Kecamatan Pasir Penyu, Kabupaten Indragiri Hulu. The data collection method used was a test in the form of essay questions, observation of teacher and student activities, and documentation.

\section{RESULTS}

This research is an application of the MIKIR approach to theme 1 , sub-theme 1 and sub-theme 2 . The learning process using the MIKIR approach triggers students to have some experiences in science, interact with other students, communicate their ideas, internalize their knowledge and reflect what they have learned. Students are invited to be directly involved observing and asking questions, students will exchange ideas and respond to the opinions of other students. Critical thinking skills that is owned by students will vary based on their abilities. The results showed that critical thinking skills experienced changes in students. Critical thinking skills in asking questions raised by 
students when the lecture process always uses open questions so that it opens and stimulates discussion between groups. The open question will solve the problem of the material being studied.

Based on the research results, the MIKIR approach can improve students' critical thinking skills on theme 1 (subtheme 1 and sub-theme 5). This can be seen from the results of the pre-test and post-test scores of students' critical thinking skills (table 2).

Table 2. Pre-test and Post-test Value Data of Students' Critical Thinking Skills

\begin{tabular}{ccc}
\hline Component & Pretest & Posttest \\
\hline Total students & 23 & 23 \\
Total score & 509 & 637 \\
Highest score & 27 & 33 \\
Lowest score & 16 & 21 \\
Average & 22,13 & 27,70 \\
Standard deviation (S) & 3,19 & 3,46 \\
Varians $\left(\mathrm{S}^{2}\right)$ & 10,20 & 11,95 \\
\hline
\end{tabular}

In Table 2 it can be seen, the total students are 23 student, all student had pretest and posttest scores. The lowest score for the student pretest was 17 and the highest score was 27, while the lowest score for the posttest was 21 and the highest score was 33., with a mean pretest score of 22.13 and an average posttest score of 27.70. Based on these results indicate that the score increased by 5.57 points or $20.10 \%$. The overall average $\mathrm{N}$-gain value is 0.41 , including the moderate criteria. This moderate category of criteria is because students have the ability to capture different learning materials, so that when the learning process uses a MIKIR approach there are some students who do not understand the material presented by the teacher.

\section{DISCUSSION}

The purpose of this research is to find out the application of the MIKIR approach to improve critical thinking skills of elementary school students. This study also showed the effectiveness of application of the MIKIR approach to improve the critical thinking skills of elementary school students.

The critical thinking skills mean to in this study are the critical thinking abilities of students which are characterized by the achievement of indicators that are able to provide simple explanations, build basic skills, infer, provide further explanation and develop strategies and tactics.

Increased critical thinking skills can be seen from the average $\mathrm{N}$-gain score of the initial and final tests is 22.13 and 27.70 with a difference is 0.41 . By looking at the test results, the critical 
thinking ability of students who obtain learning with the MIKIR approach. This shows that the application of the MIKIR approach is able to provide meaningful learning for students because it links the knowledge gained with the environment so that students critical thinking skills can be increased. In accordance with the opinion of Alpusari, et al $(2019$, p. 3$)$ that in the learning process, the students are asked to convey ideas or thoughts both orally and un writing.

From the test results illustrate that the MIKIR approach makes a positive contribution in improving students' critical thinking skills. This can be seen from the learning process that is oriented or student-centered, and is able to stimulate students to be active in learning. Interaction and communication aspects in the MIKIR approach give opportunities for student to discuss groups with their friends to learn and understand subject matter with the guidance of their friends. In accordance with the opinion of Vygotsky (in Kesuma, et al, 2010, p.10) that children's knowledge and understanding are sustained a lot by communication with others, a problem may not be solved alone, but requires the help of others. But there are also some students who are indifferent (tend to be passive) in the group, but these students understand the material provided.

In addition, an increase in students critical thinking skills is also influenced by student activities during the learning process. Activities carried out by students are part of the components of the MIKIR approach. Students are given the freedom to carry out all these components. The existence of an experiment during the learning process, then students are given the freedom of the activity. In increasing this activities the teacher needs to prepare everything in the implementation. This is in accordance with the opinion of Sudarmin (2007) explaining that science is developed based on experiments, therefore science teachers are required to have a generic ability of science awareness of high scale. One effort that can be done is to direct student research to the use of laboratories, such as the use of laboratory inquiry-based learning.

Learning by trying and observing objects has an important role to remember in the current curriculum explicitly written that one of the goals of learning in elementary schools is to provide learning experiences for students to design and create a work through the application of scientific concepts and scientific work competence wisely. therefore, learning science should be carried out in scientific inquiry to foster the ability to think, work and be scientific and communicate it as an important aspect of life skills. Therefore learning in elementary school emphasizes the provision of direct learning experiences through the use and development of scientific process skills and attitudes (BNSP, 2006).

According to Hassoubah (2007) people who think critically will evaluate and then conclude a matter based on facts to make a decision. So that one of 
the characteristics of people who think critically will always look for and explain the relationship between the problem under discussion with other relevant problems or experiences. The ability to think critically is one of the basic capital or intellectual capital that is very important for everyone, besides that according to Penner in Ibrahim (2008) this ability is a fundamental part of human maturity. Critical thinking is thinking reasoned and reflective by emphasizing decision making about what to believe and do. Critical thinking is an activity of analyzing ideas in a more specific direction, distinguishing sharply, choosing, identifying, studying and developing it in a more perfect direction. This mental process analyzes ideas and information obtained from observations, experiences, common sense and communication.

\section{CONCLUSION}

Based on the results of research and discussion, it can be concluded that by applying the MIKIR approach in learning can improve students critical thinking skills. This can be seen from the average $\mathrm{N}$-gain score of 0.41 with moderate criteria. The MIKIR approach turns out to be more effective than the learning model that has been used so that it can improve critical thinking skills. This result is supported by the results of student learning activities and student responses are obtained well. With the application of the MIKIR approach it is able to provide meaningful learning for students because it links the knowledge acquired with its environment so that students' critical thinking skills can be increased.

\section{REFERENCES}

Alpusari, M. et al. (2019). Identifying Students' Scientific Communication Skills on Vertebrata Organs. Journal of Phisics: Conference Series. 1351 (2019) 012070. doi:10.1088/1742$6596 / 1351 / 1 / 012070$

Alwi, H. (2007). Large Indonesian Dictionary. Balai Pustaka: Jakarta.

Anas, S. (2008). Introduction to Educational Evaluation. Jakarta: Raja Grafindo Persada.

Bundu, P. (2006). Assessment of Process Skills and Scientific Attitudes in Science Learning. Jakarta: Depdiknas.

Hassoubah, Z. I. (2007). Sharpening Creative and Critical Thoughts. Jakarta: Nuansa.

Hornbaek, J. \& Oulasvirta. (2017). What Is Interaction? CHI 2017 Denver, Co, USA.

http://dx.doi.org/10.1145/3025453. 3025765.

Ibrahim, M. (2008). Life Skills: Critical Thinking Skills. Journal of Education. 1 (2): 17-19.

Komalasari, K. (2013). Contextual Learning: Concepts and Applications. Bandung: PT. Refika Adiatama.

Lunenburg. F. (2010). Communication: the Process, Barriers, and Improving Effectiveness. Journal Schooling. V 1, N1. 
Purwanto, N. (2012). Principles and Techniques of Teaching Evaluation. Bandung: PT Remaja Rosdakarya.

Rusman. (2012). Cooperative Learning Model. Jakarta: Balai Pustaka.

Samatowa, U. (2011). Science Learning in elemantary Schools. Jakarta: PT Indeks.

Sanjaya, W. (2008). Learning System Planning \& Design. Jakarta: Kencana.

Sanjaya, W. (2008). Strategi Pembelajaran: Berorientasi Standar Proses Pendidikan. Jakarta: Kencana Prenada Media Group.

Sardiman (1996). Interaction and Teaching and Learning Motivation. Jakarta: PT.Raja Grafindo Persada.

Sugiyono. (2014). Metode Penelitian Kuantitatif Kualitatif dan $R \& D$. Bandung: ALFABETA.

Sunarti T. Z., \& Zuchdi (2014). Internalization and Actualization of Character Values in Junior High School Students in Phenomenological Perspectives. Journal of Development and Education: Foundation and Applications. Vol 2, No 2. P.181.
Thobroni, M \& Mustofa, A. (2013). Belajar dan Pembelajaran (Pengembangan Wacan dan Praktik Pembelajaran dalam pembangunan Nasional). Jogjakarta: Ar-Ruzz Media.

Trianto. (2010). Innovative-Progressive Learning Model Concepts, Foundations, and Implementation in Kurikulum Tingkat Satuan Pendidikan (KTSP). Jakarta: Kencana.

Velentzas, J. \& Broni, G. (2014). Communication cycle: Definition, Process, models dan examples. Recent Advances in Financial dan Product Development. 978-161804-261-3.

Widoretno, P. (2014). Development of Worksheets with Problem Based Learning on Normal Style Diagram Material, Latitude Style, and Momendi Class X TGB 1 of SMK Negeri 1 Sidoarjo. Journal of Building Engineering Education Studies 3 (1 (Online) .http: //journal.walisongo.ac.i/index.php/p hen/issue/view 31. (accessed March 23, 2020). 